ELLA MCLEAN

\title{
TOWARDS PLAIN PACKAGING: NEW ZEALAND'S WAY FORWARD IN THE REGULATION OF TOBACCO PRODUCTS
}

Submitted for the LLB (Honours) Degree

Faculty of Law

Victoria University of Wellington

2013 


\section{Contents}

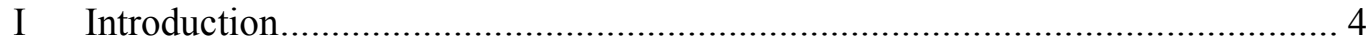

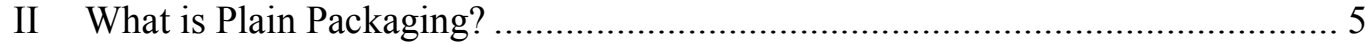

A What is the Purpose of Plain Packaging? ....................................................... 6

III Why has Plain Packaging Emerged as an Issue Internationally? ........................ 7

A The Framework Convention on Tobacco Control ........................................... 9

B Australia's Implementation of Plain Packaging ......................................... 11

C Wider International Interest in Plain Packaging ....................................... 12

1 The EU directive ............................................................................ 12

IV What Are the Particular Interests New Zealand Must Consider? .................... 14

A Public Health Considerations ..................................................................... 14

B Legitimacy of the Regulatory Regime ..................................................... 16

C New Zealand's Tobacco Industry ............................................................. 19

D New Zealand's International Obligations............................................... 21

V Should New Zealand Follow the Australian Approach? ................................... 22

A History of Alignment between New Zealand and Australia ......................... 22

B The Trans-Tasman Mutual Recognition Arrangement ................................ 23

C The Smoke-free Environments Act 1990 ...................................................... 25

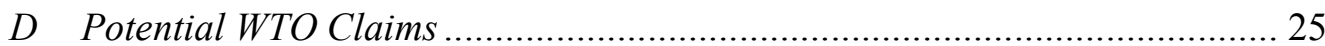

E Potential for Investment Arbitration .......................................................... 27

F Conclusions on the Potential Legal Issues of Alignment ............................... 28

VI Should New Zealand Adopt Another Approach? .............................................. 29

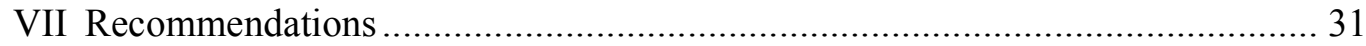

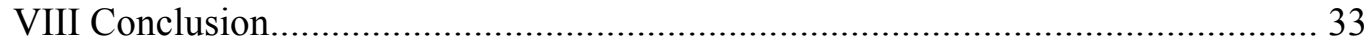

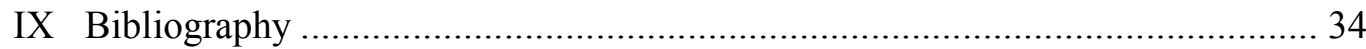




\section{Abstract}

The New Zealand Government has indicated its intention to legislate for the plain packaging of tobacco products. This paper considers what path New Zealand should take in implementing its own plain packaging regime. Consideration of New Zealand's particular interests is necessary in determining what constitutes the most appropriate approach to plain packaging for New Zealand. Whether these interests would be best represented through a policy of alignment with Australia or by implementing an alternative approach to plain packaging should inform the way in which the New Zealand Government proceeds with plain packaging. This paper considers alignment with Australia to be the most effective way to address the public health concerns presented by tobacco products and recommends that plain packaging is implemented in alignment with Australia's plain packaging regime. However, this paper also recognises that a policy of alignment gives rise to certain risks and seeks to demonstrate that there are ways in which these risks may be reduced. New Zealand should consider the implementation of certain measures to reduce the risk of investment arbitration as well as the possibility of variations on the basic position of alignment in order to reduce the risk of WTO claims against plain packaging.

\section{Key words}

Plain packaging

Tobacco products

Alignment 


\section{Introduction}

The New Zealand Government has indicated its intention to legislate for the plain packaging of tobacco products. ${ }^{1}$ The Government's February 2013 announcement followed public consultation based on the Ministry of Health's consultation document. ${ }^{2}$ This consultation document proposed a plain packaging regime aligned with that implemented in Australia, the first country in the world to have implemented plain packaging. ${ }^{3}$ Alignment was also recommended as part of the Ministry of Health's Regulatory Impact Statement on the plain packaging of tobacco products, ${ }^{4}$ and by the Māori Affairs Committee in their Inquiry into the tobacco industry in Aotearoa and the consequences of tobacco use for Māori. ${ }^{5}$ However, as the Ministry of Health's consultation document notes, there is "no requirement for continued alignment with Australia, and New Zealand will make its own decision ... on how to introduce plain packaging." 6

This paper considers the most appropriate path for New Zealand to take in the implementation its own plain packaging regime. In doing this, it takes the above recommendations of alignment as a starting point. However it is important to recognise from the outset that alignment is not the only path to plain packaging that is available to New Zealand. Part II of this paper provides essential background information to considerations of plain packaging by describing plain packaging and its purposes. Part III places the plain packaging debate in its international context. Part IV outlines some of New Zealand's interests which must be kept in mind when considering the implementation of a plain packaging regime. Part $\mathrm{V}$ considers whether New Zealand should align with Australia. Part VI looks at whether New Zealand's interests would be better served by adopting an alternative plain packaging regime. Part VII provides some recommendations based on the foregoing analysis.

\footnotetext{
${ }^{1}$ Tariana Turia "Government moves forward with plain packaging of tobacco products" (media release, 19 February 2013) <www.beehive.govt.nz>.

${ }^{2}$ Ministry of Health Proposal to introduce plain packaging of tobacco products in New Zealand: Consultation document (July 2012).

${ }^{3}$ At [2.6].

${ }^{4}$ Ministry of Health Regulatory Impact Statement: Plain Packaging of Tobacco Products (28 March 2012) at [36].

${ }^{5}$ Māori Affairs Committee Inquiry into the tobacco industry in Aotearoa and the consequences of tobacco use for Maori (3 November 2010) at 16.

${ }^{6}$ At [2.6].
} 
Implementing a plain packaging regime that fits New Zealand's particular interests is of utmost importance when legislating for regulatory reform. Unfortunately, given the diverse nature of the interests concerned, a solution addressing all interests is unachievable. Instead, these interests must be afforded appropriate weightings and a balance between competing interests must be sought. While New Zealand has certain interests that may suffer from a policy of alignment, there are persuasive reasons for implementing a plain packaging regime in alignment with Australia. However, the risks of alignment must also be recognised. This analysis suggests that New Zealand should consider variations to the basic position of alignment that may be taken to minimise these risks without undermining the central purpose of the recommended regulatory reform.

\section{What is Plain Packaging?}

Plain packaging describes the "adoption of measures to restrict or prohibit the use of logos, colours, brand images or promotional information other than brand names and product names displayed in a standard colour and font style." " Strict standardisation precludes the appearance of all visual trademarking devices, including the use of specific colours, symbols and logos. While brand and product names are permitted to allow identification, the use of these word marks is strictly regulated. Text displayed on packets must be of a certain type, size and colour. This combination of package standardisation and text regulation prevents brand differentiation through packaging. This strict regulation removes "any opportunity for tobacco companies to promote their products, or smoking behaviour in general, as being in any way desirable or attractive." $" 8$

At the time of writing Australia is the only country to have legislated for the plain packaging of tobacco products. Examples of the strict requirements set out in the Tobacco Plain Packaging Regulations 2011 (Aus) include regulations for the exact

\footnotetext{
${ }^{7}$ Guidelines for implementation of Article 11 of the WHO Framework Convention on Tobacco Control (Packaging and labelling of tobacco products) decision FCTC/COP3(10), November 2008 (Guidelines adopted by the Conference of the Parties) at [46].

${ }^{8}$ Ministry of Health, above $n$ 2, at [2.3].
} 
dimension of flip-top cigarette packs, ${ }^{9}$ and the colour of the packaging (Pantone 448C). ${ }^{10}$ The appearance of all text appearing on packaging must be printed in Lucinda Sans, in the colour Pantone Cool Grey 2C, and must be a specified size. ${ }^{11}$ Brand and variant names are allowed but must comply with these regulations. ${ }^{12}$ The Tobacco Plain Packaging Amendment Regulations 2012 (no. 1) (Aus) extends regulation to non-cigarette tobacco products such as cigars.

\section{A What is the Purpose of Plain Packaging?}

Plain packaging seeks to promote public health by reducing the desirability of tobacco products. Awareness of the dangers of tobacco consumption has led to restrictions on the promotion of tobacco products. The packaging of tobacco products has in many cases become the last remaining vehicle for brand differentiation. For example, while New Zealand's Smoke-free Environments Act 1990 prohibits the advertising and promotion of tobacco products, ${ }^{13}$ packaging continues to be used to create brand image. In this way, the packaging of tobacco products "undermines the effectiveness of measures already taken to ban tobacco products promotion and advertising". 14 The purpose of plain packaging is therefore to remove this remaining avenue of tobacco promotion. Evidence emerging from Australia since the implementation of its plain packaging regime indicates that consumers perceive tobacco products in plain packaging to be less desirable. ${ }^{15}$

In addition to undermining measures banning tobacco product advertising and promotion, the use of tobacco product packaging "undermines the effectiveness of other tobacco control initiatives." expected to bolster the effectiveness of existing tobacco control initiatives. For example, tobacco packaging undermines the display of health warnings on products as

\footnotetext{
${ }^{9}$ Tobacco Plain Packaging Regulations 2011 (Aus), reg 2.1.1.

${ }^{10}$ Regulation 2.2.1(2).

${ }^{11}$ Regulations 2.3.6(1)(a), 2.3.7(2)(c), 2.3.8(2)(c), 2.3.9(1)(a) and 2.4.1.

${ }^{12}$ Regulation 2.4.1.

${ }^{13}$ See Ministry of Health, above n 4, at [5].

${ }^{14}$ Ministry of Health, above n 4, at [3].

${ }^{15}$ Melanie A Wakefield and others "Introduction effects of the Australian plain packaging policy on adult smokers: a cross-sectional study" (2013) 3 BMJ Open.

${ }^{16}$ Ministry of Health, above $n$, at [3].
} 
"package brand imagery distracts from and therefore reduces the impact of health warnings." 17 Therefore, in addition to reducing the appeal of tobacco products, plain packaging is intended to "strengthen the impact of mandated pictorial health warnings."

Plain packaging would also address the issue of packaging being used to create false impressions about tobacco products. For example, in the Inquiry into the tobacco industry in Aotearoa and the consequence of tobacco use for Māori, the Māori Affairs Committee highlighted their concern that different packaging colours are being used to alter consumer perceptions. ${ }^{19}$ Colour associations have been developed to create perceptions that certain cigarettes are 'lighter' than others. ${ }^{20}$ This use of packaging is damaging and undermines the actions of the Commerce Commission in concluding that the use of the terms 'light' and 'mild' are misleading in themselves. ${ }^{21}$

\section{Why has Plain Packaging Emerged as an Issue Internationally?}

The idea of requiring plain packaging for tobacco products is not new. Discussion of plain packaging has existed for decades. Early discussion of plain packaging in New Zealand dates back to at least 1990. Newsletters distributed by the advocacy group Action on Smoking and Health (ASH) celebrating the enactment of the Smoke-free Environments Act 1990 indicate that ASH was already arguing for plain packaging of tobacco products at this time. ${ }^{22}$ In 1994, a panel of Canadian experts published a report named "Towards Zero Consumption: Generic Packaging of Tobacco Products. ${ }^{23}$ This report is recognised as finding that: ${ }^{24}$

\footnotetext{
${ }^{17}$ Becky Freeman, Simon Chapman and Matthew Rimmer "The case for plain packaging of tobacco products" (2008) 103 Addiction 580 at 587.

${ }^{18}$ Ministry of Health, above $\mathrm{n} 2$, at [2.2].

${ }^{19}$ At 17.

${ }^{20}$ Māori Affairs Committee, above n 5, at 17.

${ }^{21}$ Commerce Commission "Consumers warned 'light' and 'mild' tobacco likely to be just as deadly as regular strength” (media release, 24 September 2008); referred to by the Māori Affairs Committee, above $\mathrm{n} 5$, at 17.

${ }^{22}$ ASH "Victory! Bill Passed in Strengthened Form" (newsletter, August 1990) at 7.

${ }^{23}$ Canadian Standing Committee on Health Towards Zero Consumption: Generic Packaging of Tobacco Products (June 1994).

${ }^{24}$ Derek Yach "Tackling Big Tobacco: The Establishment of the Framework Convention on Tobacco Control" (2005) 26 Multinational Monitor 16 at 21.
} 
... plain and generic packaging of tobacco products through its impact on image formation and retention, recall and recognition, knowledge and consumer attitudes and perceived utilities would likely depress the incidence of smoking uptake by non-smoking teens, and increase the incidence of cessation by teen and adult smokers.

However, despite early discussion of plain packaging, Australia's 2011 legislation is the first plain packaging regime to be implemented.

What can explain the recent shift from discussion of plain packaging principles to the implementation of plain packaging regimes? As indicated above, packaging is increasingly seen as the sole remaining vehicle for advertising tobacco products. As summarised in The case for the plain packaging of cigarettes, "with the global acceleration in tobacco advertising and sponsorship bans, the pack assumes unprecedented importance as a promotional vehicle for reaching potential and current smokers." 25 Therefore we may understand the shift from words to action as a necessary response to the increasingly important promotional role that tobacco packaging has assumed over the years.

On the other hand, tobacco packaging has assumed its 'unprecedented importance' as a promotional vehicle due to bans on other forms of promotion. Many states have already implemented bans on tobacco advertising and sponsorship. Therefore, states seeking to further regulate tobacco products have fewer options available to them than in the past. Short of banning tobacco products altogether, plain packaging is one of the few remaining measures currently considered in addressing demand for tobacco products. As tobacco advertising becomes increasingly regulated the scope within which governments operate to prevent further harm has narrowed.

The developing standards of tobacco regulation have led to increasing international consideration of plain packaging. Those responsible for facilitating the negotiations that led to the World Health Organisation's Framework Convention on Tobacco

\footnotetext{
${ }^{25}$ Freeman, Chapman and Rimmer, above n 17, at 580.
} 
Control (WHO FCTC) ${ }^{26}$ have indicated that plain packaging should be the top priority' in the "next round of cutting-edge policy interventions to reduce tobaccorelated death and disease." 27 The remainder of this section will describe how plain packaging has been treated in the context of the WHO FCTC, Australia's implementation of their plain packaging regime, and proposals for similar measures internationally.

The WHO FCTC is a product of state negotiation that seeks to address public health issues that stem from tobacco consumption. ${ }^{28}$ The WHO FCTC is a binding legal instrument, imposing obligations on all of its parties. This international legal instrument reflects widespread international recognition of the importance of action on tobacco control. As at 9 September 2013, the Convention has 168 signatures and 177 parties. $^{29}$ The Convention is "one of the most widely and rapidly embraced treaties in UN history." 30

The WHO FCTC does not place parties under an obligation to implement a plain packaging regime. However, arts 11 and 13 place parties under obligations to reduce demand for tobacco product through measures aimed at 'packaging and labelling of tobacco products' ${ }^{31}$ and 'tobacco advertising, promotion and sponsorship'. ${ }^{32}$ The combination of these provisions and the guidelines for their implementation effectively raise plain packaging as an important consideration in the WHO FCTC context. Guidelines for the implementation of these provisions are proposed by the Conference of the Parties and parties may take these guidelines into account in

\footnotetext{
${ }^{26}$ WHO Framework Convention on Tobacco Control (opened for signature 16 June 2003, entered into force 27 February 2005).

${ }^{27}$ Yach, above $\mathrm{n} 24$, at 21.

${ }^{28}$ Kate Lannan "The WHO Framework Convention on Tobacco Control: the international context for plain packaging" in Tania Voon, Andrew D Mitchell and Jonathan Liberman (eds) Public Health and the Plain Packaging of Cigarettes: the legal issues (Edward Elgar Publishing, Cheltenham, 2012) at 13.

${ }^{29}$ See United Nations Treaty Collection $<$ http://treaties.un.org $>$.

${ }^{30}$ Lannan, above n 28, at 12 .

${ }^{31}$ Article 11.

${ }^{32}$ Article 13.
} 
developing "non-price measures to reduce the demand for tobacco."33 An analysis of arts 11 and 13 and their respective guidelines for implementation is thus crucial when examining the international context of plain packaging.

Article 11 of the WHO FCTC relates to the 'packaging and labelling of tobacco products'. This provision places a binding obligation on parties to take effective measures to ensure that packages and labels are not misleading and carry health warnings. Guidelines for the implementation of art 11 direct parties to consider the restriction or prohibition of "logos, colours, brand images or promotional information on packaging other than brand names and product names displayed in a standard colour and font style (plain packaging). ${ }^{34}$ The purpose of such measures is to: ${ }^{35}$

... increase the noticeability and effectiveness of health warnings and messages, prevent the package from detracting attention from them, and address industry package design techniques that may suggest that some products are less harmful than others.

This is consistent with the overall purpose of the guidelines for the implementation of art 11 which is to propose measures allowing members to "increase the effectiveness of their packaging and labelling measures." 36

Article 13 of the WHO FCTC relates to 'tobacco advertising, promotion and sponsorship'. Article 1(c) brings the packaging of tobacco products within the ambit of art 13 by defining 'tobacco advertising and promotion' widely to mean "any form of commercial communication, recommendation or action with the aim, effect or likely effect of promoting a tobacco product, or tobacco use either directly or indirectly." Article 13 requires parties to "undertake a comprehensive ban of all tobacco advertising, promotion and sponsorship." The guidelines for the implementation of art 13 recommend that parties "consider adopting plain packaging

\footnotetext{
${ }^{33}$ WHO Framework Convention on Tobacco Control, art 7.

${ }^{34}$ Guidelines for implementation of Article 11 of the WHO Framework Convention on Tobacco Control, above n 7, at [46].

${ }^{35}$ Guidelines for implementation of Article 11 of the WHO Framework Convention on Tobacco Control, above n 7, at [46].

${ }^{36}$ Guidelines for implementation of Article 11 of the WHO Framework Convention on Tobacco Control, above n 7, at [1].
} 
requirements to eliminate the effects of advertising or promotion on packaging." This suggestion follows an explanation of the ways in which the packaging of tobacco products can be used for advertising and promotional purposes. ${ }^{38}$

Articles 11 and 13 of the WHO FCTC, and the guidelines for their implementation suggest the adoption of plain packaging as a strategy within the wider battle against tobacco. These suggestions have drawn attention to the possibility of implementing plain packaging as a measure to curb the public health disaster stemming from tobacco consumption. In this way the WHO FCTC has played an important part in raising the possibility of plain packaging internationally.

\section{B Australia's Implementation of Plain Packaging}

Australia became the world leader in plain packaging with the Tobacco Plain Packaging Act 2011(Aus) receiving Royal assent on 1 December 2011. ${ }^{39}$ The Act's stated objects are to improve public health and to give effect to Australia's obligations under the WHO FCTC. ${ }^{40}$ This Act, combined with the Tobacco Plain Packaging Regulations 2011 (Aus), strictly regulates the appearance of cigarette packaging. These measures were extended to other tobacco products through the Tobacco Plain Packaging Amendment Regulations 2012 (Aus). ${ }^{41}$ From 1 December 2012, all tobacco products had to be sold in standardised packages incorporating large graphic warnings. $^{42}$

Australia's legislation exceeds what is required of it under the WHO FCTC and has been celebrated by public health officials. ${ }^{43}$ However this legislation has stimulated significant protest from the tobacco industry. This protest will be discussed in later

\footnotetext{
${ }^{37}$ Guidelines for implementation of Article 13 of the WHO Framework Convention on Tobacco Control (tobacco advertising, promotion and sponsorship) decision FCTC/COP3(12), November 2008 (Guidelines adopted by the Conference of the Parties) at [17].

${ }^{38}$ At [15].

${ }^{39}$ Australian Government; Department of Health and Aging "Plain packaging of tobacco products" $<$ www.health.gov.au>.

${ }^{40}$ Tobacco Plain Packaging Act 2011(Aus), s 3(1).

${ }^{41}$ Australian Government, above $\mathrm{n} 39$.

${ }^{42}$ Tim K Mackey, Bryan A Liang and Thomas E Novotny "Evolution of Tobacco Labeling and Packaging: International Legal Considerations and Health Governance" (2013) 103(4) American Journal of Public Health 39 at 40.

${ }^{43}$ Mackey, Liang and Novotny, above n 42, at 40.
} 
sections to the extent that it may affect New Zealand's interests in aligning itself with Australia's plain packaging regime.

\section{Wider International Interest in Plain Packaging}

While at the time of writing Australia is the only country to have legislated for the plain packaging of tobacco products, a great deal of interest exists regarding plain packaging internationally. Many countries (or groups of countries) have conducted, or are in the process of carrying out, enquiries and public consultations regarding the implementation of a plain packaging regime. The regimes being considered are not all the same. To the extent that they differ from the Australian approach, they represent possible paths New Zealand may take in implementing a plain packaging regime.

Of particular relevance is the position of the United Kingdom which issued a public consultation paper on the "standardised packaging of tobacco products" on 16 April $2012 .^{44}$ This consultation document has been of special interest to New Zealand as it includes the "publication of a systematic review of the evidence on plain tobacco packaging". ${ }^{45}$ At the time of its publication this review was the most "current and comprehensive available assessment of the research literature." 46 This review contains persuasive evidence in support of plain packaging's public health objective of reducing smoking rates. ${ }^{47}$

\section{The EU directive}

The European Union's public consultation document, Possible Revision of the Tobacco Products Directive 2001/37/EU, considered the introduction of plain or generic packaging of tobacco products for the purpose of addressing concerns over

\footnotetext{
${ }^{44}$ Department of Health (UK) Consultation on standardised packaging of tobacco products (16 April 2012); see also Cabinet Paper "Plain packaging of tobacco products" (28 June 2012) at [19].

${ }^{45}$ Cabinet Paper, above n 44, at [19].

${ }^{46}$ Cabinet Paper, above n 44, at [20].

${ }^{47}$ Cabinet Paper, above n 44, at [20].
} 
consumer information relating to tobacco products. ${ }^{48}$ Plain or generic packaging was further considered in the Proposal for a Directive of the European Parliament and of the Council on the approximation of the law, regulations and administrative provisions of the Member States concerning the manufacture, presentation and sale of tobacco and related products. ${ }^{49}$ In terms of labelling and packaging, the proposal "seeks to ensure that the appearance of the package reflects the characteristics of the product inside the package - a product that has negative health consequences, is addictive, and is not for the consumption of children and teenagers."

The proposed changes seek to eliminate any packaging elements that "promote tobacco products or mislead consumers to believe that the product is less harmful than others, refers to flavours or tastes or resembles a food product.." ${ }^{, 1}$ Regulation would include certain package requirements such as "cuboid shapes for cigarettes packages. ${ }^{, 52}$ Health warnings would also be increased to cover 75 per cent of the front and back of the packets, thus reducing the space available to feature trademarks. ${ }^{53}$ While proposed changes are a step towards plainer packaging, these measures fall well below the regulation of the Australian regime. Furthermore, in contrast to the Australian regime, the proposal is limited to cigarettes and roll-yourowns because of the particular popularity of these products among youth. ${ }^{54}$ The proposed directive does not however preclude individual countries within the European Union from implementing tighter plain packaging regulations. ${ }^{55}$

\footnotetext{
${ }^{48}$ European Commission; Health and Consumers Directorate-General (directorate C Public Health and Risk Assessment) Possible revisions of the Tobacco Products Directive 2001/37/EC: Public Consultation Document (2010) at [3.1].

${ }^{49}$ European Commission Proposal for a directive of the European Parliament and of the council on the approximation of the law, regulations and administrative provisions of the Member States concerning the manufacture, presentation and sale of tobacco and related products (19 December 2012).

${ }^{50}$ At [3.2].

${ }^{51}$ European Commission, above n 49, at [3.2].

${ }^{52}$ European Commission, above n 49, at [3.2].

${ }^{53}$ European Commission, above n 49, at [3.2]; see also Susy Frankel and Daniel Gervais "Plain Packaging and the Interpretation of the TRIPS Agreement" (2013) Vanderbilt Journal of Transitional Law (forthcoming) at 14.

${ }^{54}$ European Commission, above n 49, at [3.2].

${ }^{55}$ European Commission, above n 49, at [3.2].
} 


\section{What Are the Particular Interests New Zealand Must Consider?}

If New Zealand is to implement plain packaging in line with the Government's stated intention, it must adopt a policy that accounts for New Zealand's particular interests. These particular interests are broad and include public health considerations, the legitimacy of a plain packaging regime, New Zealand's tobacco industry and New Zealand's international obligations. These interests will be outlined below to demonstrate how they may affect considerations in the implementation of plain packaging in New Zealand.

\section{A Public Health Considerations}

Smoking is the "single biggest cause of preventable death and disease in New Zealand." ${ }^{56}$ Given the associated health risks, tobacco consumption is primarily a public health concern. This view of tobacco is reflected in the Ministry of Health's Regulatory Impact Statement which asserts that "the overarching purpose of New Zealand's tobacco control policy is to ultimately reduce smoking prevalence in New Zealand, and in doing so, to improve population health outcomes. ${ }^{, 57}$ In line with this public health purpose, the Government's stated policy is "that New Zealand be essentially smoke-free by $2025 .{ }^{, 58}$ Current trends indicate that this goal will not be met unless new initiatives, such as plain packaging, are implemented. ${ }^{59}$

According to the Key Findings of the New Zealand Health Survey, smoking rates in New Zealand are decreasing. ${ }^{60}$ When looking at New Zealand's general population, smoking rates have undergone a significant decrease; while 25 per cent of New Zealand identified as smokers in the 1996/1997 survey, this figure dropped to 17 per cent in 2011/2012. ${ }^{61}$ However, smoking rates reported amongst Māori and Pacific Island adults, and adults suffering from socioeconomic deprivation have remained above the national average.

\footnotetext{
${ }^{56}$ Cabinet Paper "Plain packaging' of tobacco products" (29 March 2012) at [15].

${ }^{57}$ At [9].

${ }^{58}$ Ministry of Health, above $\mathrm{n}$ 4, at [9].

${ }^{59}$ Ministry of Health, above $n$ 4, at [17].

${ }^{60}$ Ministry of Health The Health of New Zealand Adults 2011/12: Key findings of the New Zealand Health Survey (December 2012) at 130.

${ }^{61}$ At 130.
} 
Inconsistent smoking rates are clearly demonstrated in the data gathered in the Health Survey. Higher smoking rates have persisted amongst Māori adults with 41 per cent currently identifying as smokers. ${ }^{62}$ This shows no significant change from rates reported in 2006/2007. ${ }^{63}$ With smoking rates amongst Pacific Island adults at 26 per cent, Pacific Island adults are significantly less likely to smoke than Maori adults yet remain 1.3 times more likely to smoke than non-Pacific adults. ${ }^{64}$ Furthermore, the $2011 / 2012$ survey found that "the smoking rate for people living in the most deprived areas is 2.5 times as high as that for people living in the least deprived areas." 65 This association is particularly concerning as the figure was adjusted for age, sex and ethnic group. ${ }^{66}$

The Health Survey identified "improving the health of Māori and Pacific adults, and adults living in more deprived areas" as a key priority. ${ }^{67}$ An important aspect of this is to bring the smoking rates of these groups in line with the lower (and decreasing) trend for smoking rates amongst New Zealand adults. Specifically addressing smoking rates amongst Māori and Pacific adults, and adults suffering socioeconomic deprivation is necessary to address concerning and persistent health inequalities within New Zealand society. ${ }^{68}$ It will also improve the overall health of New Zealand and bring New Zealand closer to being smokefree by 2025 .

While the Key Findings of the New Zealand Health Survey provides a good indication of the health of New Zealand adults, rates of smoking amongst youth are not addressed. Instead information may be gathered from sources such as the National Year 10 ASH Snapshot Survey, 1999 - 2010: Trends in Tobacco Use by Students Ages $14-15$ Years. ${ }^{69}$ This survey indicates that smoking is more common among children in lower decile schools. ${ }^{70}$ This finding may be taken to reflect the high smoking rates

\footnotetext{
62 At 20 .

${ }^{63}$ At 22 and 29.

${ }^{64}$ At 23.

${ }^{65}$ At 130 .

${ }^{66}$ At 24.

${ }^{67}$ At 135 .

${ }^{68}$ Ministry of Health, above $\mathrm{n} 60$, at 135.

${ }^{69}$ ASH New Zealand National Year 10 ASH Snapshot Survey, 1999-2010: Trends in Tobacco Use by Students Aged 14-15 Years (2011).

${ }^{70}$ At 31 .
} 
amongst those living in more deprived areas. The survey also demonstrates that health inequalities between ethnic groups apply to adults and youth alike, with Māori students reporting the highest rate of 'daily' smoking at 14.1 per cent. ${ }^{71}$ Concerns regarding the high rates of smoking among Māori youth have been highlighted by the Māori Affairs Committee. ${ }^{72}$

The nature of New Zealand's particular public health concerns necessitates particular consideration of how tobacco control measures may reduce smoking among Māori, Pacific Islanders and those suffering from socioeconomic deprivation. These demographic groups should be taken into account when considering how New Zealand should implement plain packaging. The Government should pay particular attention to the recommendations of inquiries that focus on the effects of smoking among these demographic groups. The recommendation of the Māori Affairs Committee in its Inquiry into the tobacco industry in Aotearoa and the consequence of tobacco use for Mãori was that "the tobacco industry be required to provide tobacco products exclusively in plain packaging, harmonising with the proposed requirements in Australia in 2012."73

\section{B Legitimacy of the Regulatory Regime}

The objective of any plain packaging regime would be to protect New Zealand consumers from the harmful effects of tobacco consumption. Plain packaging proposals may therefore be described as paternalistic. Legal paternalism is premised on the notion that consumers must be protected from their own bad choices. This conflicts with concepts of human rationality and autonomy. Rationality and autonomy are inherent to liberty, a concept highly valued in our society. As Tokeley puts it, "[m]odern democratic societies such as New Zealand value individual liberty too highly for uncritical paternalism to be acceptable., ${ }^{, 74}$ Therefore, when considering the implementation of a plain packaging regime, policy makers must assess the regime's

\footnotetext{
71 At 14.

${ }^{72}$ Māori Affairs Committee, above n 5, at 18; see also ASH New Zealand, above n 69, at 31.

${ }^{73}$ At 16.

${ }^{74}$ Kate Tokeley “Consumer Law and Paternalism: A Framework for Policy Decision-making” in Susy Frankel and Deborah Ryder (eds) Recalibrating Behaviour: Smarter Regulation in a Global World (LexisNexis, 2013) at [7.2].
} 
legitimacy. It is in New Zealand's interests to impose paternalistic regimes only to the extent that such regimes are considered legitimate.

Tokeley's framework for considering paternalistic regulation is a useful tool for policy makers in assessing legitimacy. The considerations include ${ }^{75}$

- the magnitude of potential consumer harm;

- the probability of consumer harm;

- the irreversibility of potential consumer harm;

- the degree to which addiction is affecting consumer choice;

- the degree to which consumers want to be protected;

- the degree to which consumers are dealing with complex large quantities of information they are unable to process;

- the degree to which the problem is affecting children, young adults or other potentially disadvantaged groups;

- the degree to which there are additional, non-paternalistic reasons for enacting the law; and

- the probability of non-legal responses, such as education or support programmes, failing to provide solutions to the problem within an acceptable time frame.

These considerations are important when contemplating what path New Zealand should take towards plain packaging. While a full analysis of policy implications is outside the scope of this paper, discussion of plain packaging in light of these considerations can indicate possible perceptions of plain packaging's legitimacy.

As previously discussed, the magnitude and probability of harm that tobacco products pose to New Zealand consumers is significant. Tobacco consumption leads to irreversible life-threatening diseases. Harm is likely even where smoking is moderated. ${ }^{76}$ In addition, tobacco is a very addictive substance. Chemical addiction makes it hard for consumers to give up smoking, thus inhibiting their ability to promote their own well-being. ${ }^{77}$ In these circumstances, paternalistic intervention may

\footnotetext{
${ }_{76}^{75}$ At [7.3].

${ }^{76}$ Tokeley, above n 74, at [7.4.2].

${ }^{77}$ Tokeley, above n 74, at [7.4.4].
} 
be perceived as legitimate for there is a strong argument that the state needs to preserve citizens' interests. ${ }^{78}$ Tokeley's first four considerations therefore support the view that using plain packaging to prevent the harm caused by tobacco is a legitimate use of government power.

'Soft paternalism' aims to "nudge or encourage the consumer to change their behaviour." ${ }^{, 79}$ By eliminating promotional elements plain packaging seeks to "nudge consumers [to stop smoking], rather than force them to make better choices." ${ }^{\prime 80}$ For this reason, plain packaging may be viewed as a soft paternalistic approach. Soft paternalism is generally more palatable to consumers than 'hard paternalism' which seeks to "coerce the consumer to behave in a certain way." 81 Banning tobacco products altogether may be viewed as an example of hard paternalism. While an outright ban on tobacco products could bring New Zealand significantly closer to being smokefree by 2025 by cutting supply chains, the New Zealand public may well regard a ban as illegitimate. While tobacco companies have argued that plain packaging would "curtail individual freedoms", evidence suggests that these concerns are not widely shared by consumers. ${ }^{82}$ A study conducted in 2012 found that "few respondents $(20 \%)$ agreed with industry claims that plain packaging would be unfair." 83 This indicates that while tobacco companies have tried to undermine plain packaging by highlighting its paternalistic purposes, consumers nonetheless view plain packaging as legitimate.

While this brief overview indicates that plain packaging is likely to be seen as legitimate, this requires greater consideration. Policy makers should account for the relative legitimacy of different plain packaging regimes when considering the most appropriate regime for New Zealand. Furthermore, the legitimacy of plain packaging compared to alternative tobacco control measures is relevant. To the extent that the Government seeks to curb tobacco consumption, plain packaging may be considered more legitimate than the possible alternatives of an outright ban or raising the

\footnotetext{
${ }^{78}$ Tokeley, above n 74, at [7.4.4].

${ }^{79}$ Tokeley, above n 74, at [7.1].

${ }^{80}$ Tokeley, above n 74, at [7.5.3].

${ }^{81}$ Tokeley, above n 74, at [7.1].

${ }^{82}$ Janet Hoek and others "Strong public support for plain packaging of tobacco products" (2012) 36(5)

Australian and New Zealand Journal of Public Health 405 at 405.

${ }^{83}$ Hoek and others, above $\mathrm{n} 82$, at 407.
} 
purchase age. In this respect the relative legitimacy of plain packaging may arguably support the implementation of a plain packaging regime as an alternative to more coercive tobacco control measures.

\section{New Zealand's Tobacco Industry}

In considering New Zealand's particular interests it is important to consider whether, and to what extent, implementation of a plain packaging regime may negatively impact New Zealand industry. Policy makers should seek to implement a plain packaging regime that furthers public health aims while placing minimum costs on industry. Plain packaging's effects on domestic industry must therefore be considered as part of an overall cost-benefit analysis. The size of New Zealand's tobacco industry or any industry associated with tobacco products and the negative consequences that may stem from plain packaging are two important factors within this analysis. ${ }^{84}$ Of course, any policy that seeks to reduce demand for tobacco products will have negative long-term implications for associated industry. This is an inevitable consequence of New Zealand's public health aspirations. It is nevertheless in New Zealand's interests that the plain packaging regime implemented does not disproportionately affect New Zealand industry.

Significant opposition to plain packaging has come from retailers of tobacco products. ${ }^{85}$ Industry websites assert that the sale of tobacco products is important to the business of "approximately 7,600 outlets retailing tobacco in New Zealand." ${ }^{86}$ In particular, convenience stores (dairies, minimarts, newsagents and service stations) are reliant on these sales. ${ }^{87} \mathrm{~A}$ recurring concern seen in submissions made during public consultation is that plain packaging would increase service time thus affecting productivity and increasing risks of shoplifting. However, these concerns have been

\footnotetext{
${ }^{84}$ See Ministry of Health, above $\mathrm{n} 4$, at [31].

${ }^{85}$ This opposition is evident in the submissions made by retailers as part of the public consultation process on plain packaging in New Zealand.

${ }^{86}$ British American Tobacco New Zealand "New Zealand's tobacco industry" (17/11/2010) $<$ www.batnz.com>.

${ }^{87}$ British American Tobacco New Zealand, above n 86.
} 
largely contradicted by Australian evidence. ${ }^{88}$ Research conducted upon the implementation of Australia's plain packaging regime indicates that, after small increases in transaction times upon the regime's implementation, retailers quickly adjusted to the new packaging. Retrieval time returned to the baseline range within only two weeks of the regime being implemented. This indicates that New Zealand retailers would suffer only minor costs during this transitional period.

While further information on the extent of New Zealand's own tobacco manufacturing industry is required, the Regulatory Impact Statement indicates that the majority of tobacco products sold in New Zealand are imported. ${ }^{89}$ The vast majority of tobacco products sold in New Zealand are packaged overseas, with 85 per cent being packaged in Australia. ${ }^{90}$ Furthermore, to the extent that manufacturing does occur in New Zealand, plain packaging requirements would not represent a major cost as it is "unlikely that [manufacturers] would need to alter their premises to meet requirements." 91 Even if compliance costs did arise they are likely to be borne by tobacco companies rather than domestic manufacturers. ${ }^{92}$ Finally, to the extent that tobacco products are manufactured in New Zealand the majority are exported to Australia. ${ }^{93}$ Information available through the United Nations Commodity Trade Statistics Database indicates that Australia is by far the largest export market for New Zealand's tobacco products. ${ }^{94}$ Given that tobacco product manufacturers are required to use Australian compliant packaging if they want to continue exporting to Australia, alignment with Australia may in fact be desirable. ${ }^{95}$

If New Zealand companies are involved in designing tobacco packaging they are likely to suffer significantly if plain packaging were implemented. ${ }^{96}$ The highly

\footnotetext{
${ }^{88}$ Melanie Wakefield, Megan Bayly and Michelle Scollo "Product retrieval time in small tobacco retail outlets before and after the Australian plain packaging policy: real-world study" (2013) Tobacco Control.

${ }^{89}$ At 1.

${ }^{90}$ Māori Affairs Committee, above n 5, at 16.

${ }^{91}$ Ministry of Health, above n 4, at [23].

${ }^{92}$ Ministry of Health, above n 4, at [23].

${ }^{93}$ See Ministry of Economic Development briefing prepared for the Cabinet Social Policy Committee on 29 March 2012 Cabinet Paper "Tobacco Plain Packaging" (2012) MED1326601 at [11].

${ }^{94}$ United Nations Commodity Trade Statistics Database < http://comtrade.un.org $>$.

${ }^{95}$ Ministry of Economic Development briefing prepared for the Cabinet Social Policy Committee on September 2011 Cabinet Paper "Tobacco Plain Packaging” (2011) MED1242336 at [8]; see also Cabinet Paper, above n 56, at [24].

${ }^{96}$ Ministry of Health, above n 4, at 10.
} 
regulated packages required under a plain packaging regime means less work for design companies. However the extent of this industry sector - and therefore the extent of New Zealand's particular interests - is as yet unclear. Similarly, smaller importers may suffer if the costs of implementing plain packaging prevent suppliers from exporting to New Zealand. ${ }^{97}$ If New Zealand aligns with Australia, importing Australian products would present no issue as Australian tobacco products would already be plain packaging compliant. However, small importers of products such as Cuban cigars may be affected. While such effects are suspected to be minor, they nonetheless require further investigation and should be considered in deciding how New Zealand should implement plain packaging. ${ }^{98}$

\section{New Zealand's International Obligations}

When considering the implementation of a plain packaging regime, New Zealand must acknowledge to its various international obligations. New Zealand's obligations under the aforementioned WHO FCTC support, but do not require, the implementation of a plain packaging regime. On the other hand, a plain packaging regime may arguably breach other bilateral and multilateral treaties to which New Zealand is a party. The extent of this risk is demonstrated in the response to Australia's implementation of plain packaging (to be discussed in the following section). However, these legal issues are complex. For the purposes of this analysis it is sufficient to remember that New Zealand must seek to protect public health without "doing unnecessary collateral damage" to other obligations, such as those under international trademark and investment law. ${ }^{99}$ In opening New Zealand up to World Trade Organisation (WTO) claims and investment arbitration, a breach of international obligations may undermine New Zealand's reputation. These legal proceedings also have financial costs. Consequently, New Zealand's international obligations must be kept in mind when considering how to implement plain packaging.

\footnotetext{
${ }^{97}$ Ministry of Health, above $\mathrm{n} 4$, at 9.

${ }^{98}$ Ministry of Health, above $n$ 4, at 9.

${ }^{99}$ Frankel and Gervais, above n 53, at 51.
} 


\section{Should New Zealand Follow the Australian Approach?}

As addressed in the introduction, alignment with Australia can be taken as a starting point from which the most appropriate plain packaging regime for New Zealand is considered. Alignment has been recommended by the Māori Affairs Committee in their inquiry, ${ }^{100}$ and by the Ministry of Health in their Regulatory Impact Statement and their consultation document. ${ }^{101}$ However, before embarking on alignment with Australia it is necessary to assess the implications of alignment for New Zealand. In considering these implications, it is important to remember that plain packaging policy should be developed to best give effect to New Zealand's particular interests.

New Zealand and Australia have a history of closely aligned tobacco control policies. While this does not justify alignment with Australia's plain packaging regime in itself, it is important to consider the reasons behind this history of alignment. Analysis of historic alignment serves to highlight the pattern of emulation that has existed between New Zealand and Australia.

Tobacco control legislation in New Zealand has been significantly influenced by that of Australia. New Zealand's Smoke-free Environments Act 1990, which restricted tobacco promotion and substituted tobacco-funded sports sponsorship with sponsorship through a government-funded foundation, was inspired by the Victorian Tobacco Act $1987 .^{102}$ Similarly, health warnings on cigarette packages were adopted in New Zealand following their implementation in Australia. ${ }^{103}$ The form and content of these warnings have been essentially identical since New Zealand's adoption of new warnings in $1999 .^{104}$

\footnotetext{
${ }^{100}$ At 16.

${ }^{101}$ Ministry of Health, above n 2, at [2.6]; and Ministry of Health, above n 4, at [36].

102 Donley T Studlar "The Political Dynamics of Tobacco Control in Australia and New Zealand: Explaining Policy Problems, Instruments, and Patterns of Adoption" (2006) 40(2) Australian Journal of Political Science 255 at 264.

${ }^{103}$ Studlar, above n 102, at 264.

${ }^{104}$ Studlar, above n 102, at 266.
} 
Overall convergence between New Zealand and Australian tobacco control initiatives has come about as governments (including state and federal governments in Australia) adopt policies they perceive as successful. ${ }^{105}$ While New Zealand has often followed Australia's lead, New Zealand's Smoke-free Environments Act 1990 represented a comprehensive government strategy on tobacco, something Australia lacked until 1994. ${ }^{106}$ This pattern of emulation has led New Zealand and Australia to be seen as world leaders in tobacco control. ${ }^{107}$ The historic successes of emulation supports its continuation - but only if applied to successful policies. While this pattern of emulation indicates that alignment can work well, it is vitally important that New Zealand considers whether alignment with Australia is in its own interests. Whether the plain packaging of tobacco products should follow this pattern of emulation is the question to be considered here.

\section{B The Trans-Tasman Mutual Recognition Arrangement}

The commencement of Australia's plain packaging regime required tobacco products to be temporarily exempted from mutual recognition under the Trans-Tasman Mutual Recognition Arrangement (TMMRA). Australia effected this temporary exemption through regulation. ${ }^{108}$ If this measure had not been instigated prior to Australia's implementation of plain packaging, products that met New Zealand's tobacco packaging requirements could have been sold in Australia despite not complying with the new regulations. This would have undermined Australia's plain packaging policy completely. The New Zealand Government agreed early on not to "create any impediment to Australia's implementation of plain packaging", and has worked with the Australian Government to "ensure that no branded tobacco is able to be reexported from New Zealand to Australia."

The temporary exemption on tobacco products was put in place for 12 months. ${ }^{110}$ This timeframe was implemented to allow New Zealand time to consider alignment with

\footnotetext{
${ }^{105}$ Studlar, above n 102, at 260-261

${ }^{106}$ Studlar, above n 102, at 261.

${ }^{107}$ Studlar, above n 102, at 255.

${ }^{108}$ Ministry of Health, above n 2, at [2.6], n 5.

${ }^{109}$ Cabinet Paper, above n 56, at [34]

${ }^{110}$ Cabinet Paper, above n 56, at [36]
} 
Australia. ${ }^{111}$ Alignment may involve 'full harmonisation' in which New Zealand simply adopts Australia's plain packaging requirements. ${ }^{112}$ However, a more practical option is to seek 'mutual recognition' in which New Zealand adopts an equivalent regime. ${ }^{113}$ Mutual recognition describes the state between New Zealand and Australia before the temporary exemption for tobacco products was asserted. This allowed for minor divergences in regulation (such as the use of Māori health warnings in New Zealand and country specific Quitline numbers). ${ }^{114}$ However, if a New Zealand equivalent of the Australian regime is not adopted then mutual recognition will not be reasserted. ${ }^{115}$ Instead a permanent exemption would be sought by Australia. ${ }^{116}$

The granting of a permanent exemption under the TTMRA is regarded as a 'last resort' ${ }^{117}$ This is because permanent exemptions undermine the effectiveness of the TTMRA and the principle of a single economic market. ${ }^{118}$ The effects of a single economic market are evident in the significant trade that exists in tobacco products between New Zealand and Australia. ${ }^{119}$ Given the New Zealand Government's promise not to impede Australia's plain packaging regime, alignment is necessary if a single economic market in tobacco products is to remain intact. To this extent, the principles underpinning the TTMRA support New Zealand's alignment with Australia, at least to the point of mutual recognition. However, it is possible for tobacco products to be permanently exempted from the TMMRA. Therefore the effectiveness of the TTRMA and the principle of a single economic market are only factors in support of alignment. Furthermore, the weight of this support is dependent on the degree to which a single economic market in tobacco products is desirable. Therefore, the TTMRA should not preclude consideration of alternative plain packaging regimes that fall outside its scope.

\footnotetext{
${ }^{111}$ Ministry of Health, above $\mathrm{n} 2$, at 8 .

112 Cabinet Paper "Plain packaging of tobacco products" (September 2011) at [31].

${ }^{113}$ Cabinet Paper, above n 112, at [31].

${ }^{114}$ Cabinet Paper, above n 112, at [32].

${ }^{115}$ Cabinet Paper, above n 56 at [36].

${ }^{116}$ Cabinet Paper, above n 56, at [36].

${ }^{117}$ Cabinet Paper, above n 56, at [36].

${ }^{118}$ Cabinet Paper, above n 56, at [24].

${ }^{119}$ See discussion in New Zealand's Tobacco Industry.
} 
New Zealand's current tobacco control legislation has the stated purpose of facilitating "the harmonisation of the laws of New Zealand and Australia relating to the labelling of tobacco products (including, without limitation, requirements relating to the display of health messages)." ${ }^{, 120}$ This purpose was introduced through s 6 of the Smoke-free Environments Amendment Act 1997. ${ }^{121}$ This change was effected in the months before the passage of the Trans-Tasman Mutual Recognition Act 1997. It is probable that this purpose was introduced to facilitate the harmonisation of New Zealand and Australian laws before the introduction of legislation giving effect to the TTMRA.

To the extent that New Zealand's tobacco control legislation supports harmonisation with Australia, alignment may be regarded as desirable. If New Zealand does not follow Australia's lead, requirements for the labelling of tobacco products in the two jurisdictions will arguably be out of step. However, it may also be argued that New Zealand and Australian labelling requirements are consistent and Australia is simply taking a further step in terms of packaging requirements. Therefore, the Smoke-free Environments Act 1990 may not provide a strong argument for alignment with Australia's plain packaging regime. It does however supplement the argument, based on TTMRA principles, that harmonisation between New Zealand and Australia is desirable. $^{122}$

\section{Potential WTO Claims}

While Australia's move to plain packaging has been widely commended, it has also led to widespread protest by the tobacco industry and tobacco exporting countries. If New Zealand aligns itself with Australia, it is likely that New Zealand will become the subject of similar protest. ${ }^{123}$ WTO claims have been brought against Australia alleging breaches of the WTO Agreement on Trade-Related Aspects of Intellectual

\footnotetext{
${ }^{120}$ Smoke-free Environments Act 1990, s 21(c).

${ }^{121}$ Smoke-free Environments Amendment Act 1997, s 6.

${ }^{122}$ See discussion in The Trans-Tasman Mutual Recognition Arrangement

${ }^{123}$ Ministry of Health, above $\mathrm{n}$ 4, at 10/11.
} 
Property Rights (TRIPS), ${ }^{124}$ the WTO Technical Barriers to Trade (TBT) Agreement, ${ }^{125}$ and the General Agreement on Tariffs and Trade (GATT). ${ }^{126}$ Like Australia, New Zealand is a party to these multilateral trade agreements.

At the time of writing claims brought by Honduras, ${ }^{127}$ the Dominican Republic, ${ }^{128}$ and Cuba, ${ }^{129}$ are in the process of consultation, while a panel to hear the Ukraine's claim is established but not yet composed. ${ }^{130}$ Whether these claims are upheld remains to be seen. The likelihood of the claims succeeding is a matter of controversy despite Australian academics arguing that there has been no breach of Australia's trade obligations. ${ }^{131}$ Given that alignment with Australia carries a risk of identical WTO claims being made against it, New Zealand should closely watch the progress of these proceedings (New Zealand is in fact already a third party to the WTO proceedings between Australia and the Ukraine). ${ }^{132}$ The risk of a claim being made against New Zealand is a cost that should be taken into account when considering the possibility of alignment with Australia's plain packaging regime.

\footnotetext{
${ }^{124}$ Marrakesh Agreement Establishing the World Trade Organisation 1869 UNTS 3 (opened for signature 15 April 1994, entered into force 1 January 1995) annex 1C ('Trade-Related Aspects of Intellectual Property Rights').

${ }^{125}$ Marrakesh Agreement Establishing the World Trade Organisation 1867 UNTS 3 (opened for signature 15 April 1994, entered into force 1 January 1995) annex 1A ('Technical Barriers to Trade'). ${ }^{126}$ Marrakesh Agreement Establishing the World Trade Organisation 1867 UNTS 3 (opened for signature 15 April 1994, entered into force 1 January 1995) annex 1A ( 'General Agreement on Tariffs and Trade 1994').

${ }^{127}$ Australia - Certain Measures Concerning Trademarks, Geographical Indications and Other Plain Packaging Requirements Applicable to Tobacco Products and Packaging (Honduras v Australia) WT/DS435/R (in consultations, 4 April 2012).

${ }^{128}$ Australia - Certain Measures Concerning Trademarks, Geographical Indications and Other Plain Packaging Requirements Applicable to Tobacco Products and Packaging (Dominican Republic v Australia) WT/ DS 441/R (in consultations, 18 July 2012).

${ }^{129}$ Australia - Certain Measures Concerning Trademarks, Geographical Indications and Other Plain Packaging Requirements Applicable to Tobacco Products and Packaging (Cuba v Australia) WT/DS458/R (in consultations, 3 May 2013).

${ }^{130}$ Australia - Certain Measures Concerning Trademarks and Other Plain Packaging Requirements Applicable to Tobacco Products and Packaging (Ukraine v Australia) WT/DS434/R (panel established but not yet composed, 28 September 2012).

${ }^{131}$ See Tania Voon and Andrew D Mitchell "Implications of WTO law for the plain packaging of tobacco products" in Tania Voon, Andrew D Mitchell and Jonathan Liberman (eds) Public Health and the Plain Packaging of Cigarettes: the legal issues (Edward Elgar Publishing, Cheltenham, 2012). and Mark Davison, "The legitimacy of plain packaging under international intellectual property law: why there is no right to use a trademark under either the Paris Convention or the TRIPS Agreement" in Tania Voon, Andrew D Mitchell and Jonathan Liberman (eds) Public Health and the Plain Packaging of Cigarettes: the legal issues (Edward Elgar Publishing, Cheltenham, 2012).

${ }^{132}$ Ministry of Foreign Affairs and Trade submission to Minister of Trade "WTO Dispute Settlement: Australia Tobacco Case - Additional Claims" (16 April 2012) at 2.
} 
Tobacco companies may themselves mount challenges to plain packaging regimes based on alleged violations of international investment agreements containing investor-state dispute settlement (ISDS) clauses. If such claims succeed the result of investment arbitration will include a payment of compensation "based on the loss in value of the company's investments including its trademarks." ${ }^{, 133}$ Such a challenge has been mounted against Australia by Phillip Morris Asia Limited (PMA). While this challenge was based on a bilateral investment treaty existing between Hong-Kong and Australia, ${ }^{134}$ Australia's experience should be used to inform New Zealand's position and to highlight the possibility of a challenge based on an investment agreement to which New Zealand is party.

Investment arbitration between Australia and PMA is likely to represent the "high water mark for an investment claim against plain packaging." 135 This is because PMA would have brought its claim under the agreement it saw as promising the highest likelihood of success. ${ }^{136}$ Accordingly, the arbitral panel's conclusion on this matter will be an important indication of the extent to which plain packaging is acceptable under international investment agreements. In this way, this dispute may guide countries considering a plain packaging regime and may allow countries to protect themselves from similar challenges.

New Zealand may learn from Australia's experience and act pre-emptively to "modify the terms and scope of [investment treaties] in order to restrict future claims to the extent that parties did not intend ISDS to be used to attack health regulations". ${ }^{137}$ Measures to this effect may involve "removing investments and investors from the scope of the agreement or an ISDS mechanism", 138 "[removing] the ISDS mechanism

\footnotetext{
${ }^{133}$ Ministry of Health, above $\mathrm{n}$ 4, at 11 .

${ }^{134}$ Agreement between the Government of Hong Kong and the Government of Australia for the Promotion and Protection of Investments 1748 UNTS 385 (signed 15 September 1993, entered into force 15 October 1993).

${ }^{135}$ Tania Voon and Andrew D. Mitchell "Implications of international investment law for plain tobacco packaging: lessons from the Hong Kong-Australia BIT" in Tania Voon, Andrew D Mitchell and Jonathan Liberman (eds) Public Health and the Plain Packaging of Cigarettes: the legal issues (Edward Elgar Publishing, Cheltenham, 2012) at 172.

${ }^{136}$ Voon and Mitchell, above n 135, at 172.

${ }^{137}$ Voon and Mitchell, above n 135, at 172.

${ }^{138}$ Voon and Mitchell, above n 135, at 146.
} 
altogether", 139 "[clarifying] the scope of investment obligations" either through a side letter or interpretation, ${ }^{140}$ or including an exception to the obligations under the treaty. ${ }^{141}$ In taking these measures New Zealand may avoid the risk of investment arbitration it would otherwise be exposed to. However, such modifications depend on agreement between the parties to the treaty. Furthermore, while avoiding the risk of investment arbitration is in New Zealand's interest this may not outweigh possible negative implications stemming from the measures suggested.

\section{F Conclusions on the Potential Legal Issues of Alignment}

Australia's experiences indicate that implementing a plain packaging regime in alignment with Australia carries the risk of both WTO claims and investment arbitration. New Zealand must consider these legal disputes. While Australia has argued the legality of its plain packaging regime at international law, these disputes remain to be settled. Therefore New Zealand should critically consider whether alignment with Australia would breach its international obligations, either under WTO agreements to which it is party or under its own investment agreements.

Even if alignment with Australia would not breach New Zealand's international obligations, the cost of defending WTO and investment claims is significant. The Ministry of Foreign Affairs estimates that a WTO claim would cost New Zealand \$1.5-2million simply to defend the legal action. ${ }^{142}$ Furthermore, "an international investment arbitration would likely be at least as high and potentially substantially higher [than \$1.5-2million] due to the need for specialist legal and financial advice." ${ }^{143}$ Anecdotal evidence indicates that an average investment arbitration case costs each party between $\$ 3-6$ million. ${ }^{144}$

\footnotetext{
${ }^{139}$ Voon and Mitchell, above n 135, at 146

${ }^{140}$ Voon and Mitchell, above n 135, at 148.

${ }^{141}$ Voon and Mitchell, above n 135, at 148.

${ }^{142}$ Ministry of Health, above $n$ 4, at [23].

${ }^{143}$ Ministry of Health, above n 4, at [23].

${ }^{144}$ Ministry of Health, above n 4, at [23].
} 
If New Zealand waits for the outcome of cases against Australia this may influence whether or not New Zealand is subjected to a similar challenge. ${ }^{145}$ However, WTO proceedings are still in preliminary stages with only the Ukraine's claim having proceeded beyond consultations. ${ }^{146}$ Although a 60 -day consultation period is provided for, ${ }^{147}$ evidence suggests that most consultation periods last between $5-15$ months. ${ }^{148}$ The time between the establishment of a panel, and the dispute settlement body's consideration of the panel's report for adoption, should generally not exceed nine months. ${ }^{149}$ However, this is subject to extension through appeal or through the agreement of parties. ${ }^{150}$ Therefore it is hard to predict how long it will take for these disputes to be resolved.

It is in New Zealand's interests to consider whether there is an alternative path to plain packaging that does not expose it to potential WTO claims or investment arbitration. While the outcome of claims made against Australia at the WTO may affect the risk of similar claims being made against New Zealand, the timeframe of these decisions is uncertain. Given this uncertainty and the importance of New Zealand's health New Zealand should be actively considering the extent of this risk and whether it may do anything to alleviate this risk. At the same time New Zealand should consider how it may protect itself from the risk of investment arbitration. Any steps that may be taken to avoid costly legal proceedings are important considerations.

\section{Should New Zealand Adopt Another Approach?}

New Zealand has no obligation to follow Australia's lead when implementing its own plain packaging regime. Therefore, it is also important to consider alternative

\footnotetext{
${ }^{145}$ Ministry of Health, above n 4, at [23].

${ }^{146}$ See World Trade Organisation "Dispute Settlement: The Disputes" <www.wto.org $>$.

${ }^{147}$ Marrakesh Agreement Establishing the World Trade Organisation 1869 UNTS 3 (opened for signature 15 April 1994, entered into force 1 January 1995) annex 2 ('Understanding on the Rules and Procedures Governing the Settlement of Dispute') art 4.7 [hereinafter referred to as Dispute Settlement Understanding].

${ }^{148}$ OL Wethington "Commentary on the Consultation Mechanism under the WTO Dispute Settlement Understanding during Its First Five Years," (1999-2000) 31 Law and Policy in International Business 583 at 585 .

${ }^{149}$ Dispute Settlement Understanding, art 20.

${ }^{150}$ Dispute Settlement Understanding, art 20.
} 
approaches to plain packaging and whether these would better serve New Zealand's particular interests; achieving public health objectives without undermining other interests discussed above. ${ }^{151}$ The proposed EU directive represents an alternative to Australia's plain packaging regime. ${ }^{152}$ Proposed changes to the EU directive include limiting the scope for trademark use and prohibiting packaging elements that promote tobacco products or mislead customers. Therefore, although the proposed changes would not constitute plain packaging in the way the term is used to describe the Australian regime, the proposed EU directive nevertheless incorporates plain packaging elements. ${ }^{153}$

While the proposed EU directive limits the scope for trademark use, it would nevertheless allow continued use of a mark in order to "maintain its well-known status...(for certain trademarks at least)." ${ }^{154}$ This is preferable to the Australian regime in terms of trademark and intellectual property law. However, it is unclear whether the measures of the proposed EU directive would significantly contribute to New Zealand's goal of being essentially smokefree by 2025 . While the directive would prohibit misleading elements of tobacco packaging, this has already occurred in New Zealand. ${ }^{155}$ Furthermore, the proposed EU directive would result in larger health warnings, a change that has already been considered in the Ministry of Health's Regulatory Impact Statement. Despite concluding that increasing health warnings to cover 80 per cent of package fronts would probably lower smoking rates, the Ministry of Health nevertheless preferred the plain packaging option. Implementing a regime based on the proposed EU directive "does not fully address the gap in the ban on tobacco advertising, which undermines the effectiveness of other tobacco control measures."156

\footnotetext{
${ }^{151}$ See discussion in What are the Particular Interests New Zealand Must Consider?

${ }^{152}$ See discussion in The EU directive.

${ }^{153}$ See discussion in What is Plain Packaging?

${ }^{154}$ Frankel and Gervais, above n 53, at 36.

${ }^{155}$ Commerce Commission, above n 21; see also Māori Affairs Committee, above n 5, at 17.

${ }^{156}$ Ministry of Health, above $\mathrm{n}$ 4, at [21].
} 


\section{Recommendations}

New Zealand should implement a plain packaging regime in alignment with Australia. Alignment with Australia is desirable as Australia's plain packaging regime effectively removes the remaining vestiges of tobacco advertising. Evidence emerging from Australia indicates that the elimination of advertising has been effective in reducing the demand for tobacco products. ${ }^{157}$ Therefore, if the Government is committed to realising its goal of an essentially smokefree New Zealand by 2025, it must be serious about implementing a strategy of this kind as part of a more comprehensive strategy to combat tobacco consumption in New Zealand. Implementation of a policy based on the proposed EU directive would be less effective in eliminating the remaining vestiges of tobacco advertising than alignment with Australia. The extent to which the proposed directive's measures would have effect in New Zealand should be questioned given New Zealand's relatively strict tobacco regulation.

New Zealand's alignment with Australia's plain packaging regime is supported by the principles of harmonisation and a single market approach. Such principles are central to the TTMRA and are echoed in New Zealand's own Smoke-free Environments Act 1990. However the significance of maintaining a single economic market for tobacco products may be questioned. One factor that could be seen as supporting the principle of a single economic market in tobacco products is the state of trade in tobacco products between New Zealand and Australia. Given that Australia represents a very significant export market of tobacco products that are manufactured in New Zealand, alignment with Australia would be a practical approach to plain packaging. ${ }^{158}$ This is because New Zealand compliant tobacco products could be sold in Australia under the TTMRA, eliminating the need for New Zealand exporters to use different packages for products destined for Australia. Alignment with Australia is expected to result in "certain cost efficiencies" making a policy of alignment a desirable path to plain packaging as far as New Zealand's tobacco industry is concerned. ${ }^{159}$

\footnotetext{
${ }^{157}$ Wakefield, above n 15.

${ }^{158}$ See discussion in New Zealand's Tobacco Industry.

${ }^{159}$ Cabinet Paper, above n 56, at [24].
} 
Potential legal issues would arise from alignment with Australia's plain packaging regime. New Zealand should learn from Australia's experience of plain packaging and use it to reduce the risk presented by legal proceedings. PMA's claim against Australia is instructive as it highlights the potential for investment arbitration over plain packaging. The dispute, and the literature that has been produced in response to it, should be used to guide New Zealand in terms of investment treaties and ISDS provisions. ${ }^{160}$ New Zealand should consider the possibility of excluding the tobacco industry from the scope of international investment agreements, should interpret provisions protecting a government's right to act in the public interest in a way that includes plain packaging, and should consider avoiding ISDS provisions in its international investment agreements altogether. ${ }^{161}$

Finally the risk of WTO claims remains. To some extent, New Zealand may have to accept this risk if it is going to pursue alignment. However, New Zealand should consider the possibility of minor alterations to the basic position of alignment that may be taken to alleviate this risk. One possible measure is to restrict the scope of plain packaging. Restricting plain packaging to cigarettes and roll-your-own's may limit the extent of legal claims resulting from a plain packaging regime. Any claims may also have a better basis upon which public health justifications could be claimed. While evidence is not yet gathered it is highly likely that the priority populations in terms of public health overwhelming use cigarettes and roll-your-owns as opposed to cigars (which are more expensive making their use amongst youth and the subjects of socioeconomic deprivation unlikely). This approach echoes that of the proposed EU directive and while it would lead to some inconsistency with Australia, it is unlikely to undermine alignment as a whole. Although any variation requires its own analysis this example demonstrates how New Zealand may consider possible variations.

\footnotetext{
${ }^{160}$ See Voon and Mitchell, above n 135.

${ }^{161}$ See discussion in Potential for Investment Arbitration.
} 


\section{Conclusion}

Consideration of New Zealand's interests supports the implementation of a plain packaging regime in alignment with Australia. This policy of alignment is a continuation of a pattern of emulation between New Zealand and Australia, allowing (once again) for New Zealand to piggyback on an Australian initiative in a costeffective manner. To the extent that this policy exposes New Zealand to risks of legal proceedings there is scope to reduce these risks. Certain measures should be considered that would reduce the risk of investment arbitration. The possibility of making minor alterations to the basic position of alignment should also be considered to the extent that such measures may reduce the risk of WTO claims. 


\section{Bibliography}

\section{A Legislation (do not include country identifiers)}

$1 \quad$ New Zealand

Smoke-free Environments Act 1990.

Smoke-free Environments Amendment Act 1997.

Trans-Tasman Mutual Recognition Act 1997.

$2 \quad$ Australia

Tobacco Plain Packaging Act 2011.

Victorian Tobacco Act 1987.

Tobacco Plain Packaging Amendment Regulations 2012 (No. 1).

Tobacco Plain Packaging Regulations 2011.

\section{B Government Reports}

$1 \quad$ New Zealand

Māori Affairs Committee Inquiry into the tobacco industry in Aotearoa and the consequences of tobacco use for Maori (3 November 2010).

Ministry of Health Proposal to introduce plain packaging of tobacco products in New Zealand: Consultation document (July 2012).

Ministry of Health Regulatory Impact Statement: Plain Packaging of Tobacco Products (28 March 2012).

Ministry of Health The Health of New Zealand Adults 2011/12: Key findings of the New Zealand Health Survey (December 2012).

\section{$2 \quad$ Canada}

Canadian Standing Committee on Health Towards Zero Consumption: Generic Packaging of Tobacco Products (June 1994).

\section{United Kingdom}

Department of Health (UK) Consultation on standardised packaging of tobacco products (16 April 2012). 
European Commission Proposal for a directive of the European Parliament and of the council on the approximation of the law, regulations and administrative provisions of the Member States concerning the manufacture, presentation and sale of tobacco and related products (19 December 2012).

European Commission; Health and Consumers Directorate-General (directorate $\mathrm{C}$ Public Health and Risk Assessment) Possible revisions of the Tobacco Products Directive 2001/37/EC: Public Consultation Document (2010).

\section{Non-governmental Reports}

ASH New Zealand National Year 10 ASH Snapshot Survey, 1999-2010: Trends in Tobacco Use by Students Aged 14-15 Years (2011).

\section{Official Government Documents.}

Cabinet Paper "Plain packaging of tobacco products" (September 2011).

Cabinet Paper "Plain packaging' of tobacco products" (29 March 2012).

Cabinet Paper "Plain packaging of tobacco products" (28 June 2012).

Ministry of Economic Development briefing prepared for the Cabinet Social Policy Committee on September 2011 Cabinet Paper "Tobacco Plain Packaging" (2011) MED1242336.

Ministry of Economic Development briefing prepared for the Cabinet Social Policy Committee on 29 March 2012 Cabinet Paper "Tobacco Plain Packaging" (2012) MED1326601.

Ministry of Foreign Affairs and Trade submission to Minister of Trade "WTO Dispute Settlement: Australia Tobacco Case - Additional Claims" (16 April 2012).

\section{E Media Releases}

Commerce Commission "Consumers warned 'light' and 'mild' tobacco likely to be just as deadly as regular strength" (media release, 24 September 2008).

Turia, Tariana "Government moves forward with plain packaging of tobacco products" (media release, 19 February 2013) <www.beehive.govt.nz>. 


\section{F Newsletters}

ASH New Zealand "Victory! Bill Passed in Strengthened Form" (newsletter, August 1990).

\section{G Treaties \\ $1 \quad$ Multilateral}

Marrakesh Agreement Establishing the World Trade Organisation 1867 UNTS 3 (opened for signature 15 April 1994, entered into force 1 January 1995) annex 1A ('General Agreement on Tariffs and Trade 1994').

Marrakesh Agreement Establishing the World Trade Organisation 1867 UNTS 3 (opened for signature 15 April 1994, entered into force 1 January 1995) annex 1A ('Technical Barriers to Trade').

Marrakesh Agreement Establishing the World Trade Organisation 1869 UNTS 3 (opened for signature 15 April 1994, entered into force 1 January 1995) annex 1C ('Trade-Related Aspects of Intellectual Property Rights').

Marrakesh Agreement Establishing the World Trade Organisation 1869 UNTS 3 (opened for signature 15 April 1994, entered into force 1 January 1995) annex 2 ('Understanding on the Rules and Procedures Governing the Settlement of Dispute').

WHO Framework Convention on Tobacco Control (opened for signature 16 June 2003, entered into force 27 February 2005).

\section{$2 \quad$ Bilateral}

Agreement between the Government of Hong Kong and the Government of Australia for the Promotion and Protection of Investments 1748 UNTS 385 (signed 15 September 1993, entered into force 15 October 1993).

\section{H Guidelines to Treaties}

Guidelines for implementation of Article 11 of the WHO Framework Convention on Tobacco Control (Packaging and labelling of tobacco products) decision FCTC/COP3(10), November 2008 (Guidelines adopted by the Conference of the Parties).

Guidelines for implementation of Article 13 of the WHO Framework Convention on Tobacco Control (tobacco advertising, promotion and sponsorship) decision FCTC/COP3(12), November 2008 (Guidelines adopted by the Conference of the Parties). 
Australia - Certain Measures Concerning Trademarks and Other Plain Packaging Requirements Applicable to Tobacco Products and Packaging (Ukraine v Australia) WT/DS434/R (panel established but not yet composed, 28 September 2012).

Australia - Certain Measures Concerning Trademarks, Geographical Indications and Other Plain Packaging Requirements Applicable to Tobacco Products and Packaging (Cuba v Australia) WT/DS458/R (in consultations, 3 May 2013).

Australia - Certain Measures Concerning Trademarks, Geographical Indications and Other Plain Packaging Requirements Applicable to Tobacco Products and Packaging (Dominican Republic v Australia) WT/ DS 441/R (in consultations, 18 July 2012).

Australia - Certain Measures Concerning Trademarks, Geographical Indications and Other Plain Packaging Requirements Applicable to Tobacco Products and Packaging (Honduras v Australia) WT/DS435/R (in consultations, 4 April 2012).

\section{J Internet Materials}

Australian Government; Department of Health and Aging "Plain packaging of tobacco products" <www.health.gov.au>.

British American Tobacco New Zealand "New Zealand's tobacco industry" $(17 / 11 / 2010)<w w w . b a t n z . c o m>$.

Plain Packs Aotearoa <www. plainpacks.org.nz>.

United Nations Commodity Trade Statistics Database $<$ http://comtrade.un.org $>$.

United Nations Treaty Collection $<$ http://treaties.un.org $>$.

World Trade Organisation "Dispute Settlement: The Disputes" <www.wto.org $>$.

\section{K Books and chapters in books}

Davison, Mark "The legitimacy of plain packaging under international intellectual property law: why there is no right to use a trademark under either the Paris Convention or the TRIPS Agreement" in Tania Voon, Andrew D Mitchell and Jonathan Liberman (eds) Public Health and the Plain Packaging of Cigarettes: the legal issues (Edward Elgar Publishing, Cheltenham, 2012).

Lannan, Kate "The WHO Framework Convention on Tobacco Control: the international context for plain packaging" in Tania Voon, Andrew D Mitchell and 
Jonathan Liberman (eds) Public Health and the Plain Packaging of Cigarettes: the legal issues (Edward Elgar Publishing, Cheltenham, 2012).

Tokeley, Kate "Consumer Law and Paternalism: A Framework for Policy Decisionmaking" in Susy Frankel and Deborah Ryder (eds) Recalibrating Behaviour: Smarter Regulation in a Global World (LexisNexis 2013).

Voon, Tania and Andrew D. Mitchell "Implications of international investment law for plain tobacco packaging: lessons from the Hong Kong-Australia BIT" in Tania Voon, Andrew D Mitchell and Jonathan Liberman (eds) Public Health and the Plain Packaging of Cigarettes: the legal issues (Edward Elgar Publishing, Cheltenham, 2012).

Voon, Tania and Andrew D Mitchell "Implications of WTO law for the plain packaging of tobacco products" in Tania Voon, Andrew D Mitchell and Jonathan Liberman (eds) Public Health and the Plain Packaging of Cigarettes: the legal issues (Edward Elgar Publishing, Cheltenham, 2012).

\section{Articles}

Frankel, Susy, and Daniel Gervais "Plain Packaging and the Interpretation of the TRIPS Agreement" (2013) Vanderbilt Journal of Transitional Law (forthcoming).

Freeman, Becky, Simon Chapman and Matthew Rimmer "The case for plain packaging of tobacco products" (2008) 103 Addiction 580.

Hoek, Janet and others "Strong public support for plain packaging of tobacco products" (2012) 36(5) Australian and New Zealand Journal of Public Health 405.

Mackey, Tim K, Bryan A Liang and Thomas E Novotny "Evolution of Tobacco Labeling and Packaging: International Legal Considerations and Health Governance" (2013) 103(4) American Journal of Public Health 39.

Studlar, Donley T "The Political Dynamics of Tobacco Control in Australia and New Zealand: Explaining Policy Problems, Instruments, and Patterns of Adoption" (2006) 40(2) Australian Journal of Political Science 255.

Wakefield, Melanie A and others "Introduction effects of the Australian plain packaging policy on adult smokers: a cross-sectional study" (2013) 3 BMJ Open.

Wakefield, Melanie, Megan Bayly and Michelle Scollo "Product retrieval time in small tobacco retail outlets before and after the Australian plain packaging policy: real-world study" (2013) Tobacco Control.

Wethington, OL "Commentary on the Consultation Mechanism under the WTO Dispute Settlement Understanding during Its First Five Years," (1999-2000) 31 Law and Policy in International Business 583. 
Yach, Derek "Tackling Big Tobacco: The Establishment of the Framework Convention on Tobacco Control" (2005) 26 Multinational Monitor 16.

Word Count: 7999 (excluding title, contents, abstracts, footnotes and bibliography). 